\title{
Päätoimisten maatilayrittäjien henkinen hyvinvointi
}

\author{
Marja Kallioniemi ${ }^{1)}$, Ahti Simola ${ }^{2)}$, Hanna-Riitta Kymäläinen ${ }^{3)}$, Hannu Vesala ${ }^{4)}$ ja Kyösti Louhelai- \\ nen $^{5)}$ \\ ${ }^{1)}$ MTT Taloustutkimus, os. MTT Vihti, Vakolantie 55, 03400 Vihti, marja.kallioniemi@mtt.fi \\ ${ }^{2)}$ Työterveyslaitos, Työyhteisöt ja organisaatiot, os. PL 486, 33101 Tampere, ahti.simola@ttl.fi \\ ${ }^{3)}$ Helsingin yliopisto, Agroteknologian laitos, os. PL 28, 00014 Helsingin yliopisto, \\ hanna-riitta.kymalainen@helsinki.fi \\ 4) MTT Taloustutkimus, os.Luutnantintie 13,00410 Helsinki, hannu.vesala@mtt.fi \\ ${ }^{5)}$ Työterveyslaitos, Työympäristön kehittäminen, os. PL 93, 70701 Kuopio, kyosti.louhelainen@ttl.fi
}

Työterveyslaitos toteutti vuonna 2004 seurantatutkimuksen päätoimisten maatiloilla työskentelevien henkilöiden työterveydestä. Puhelinkyselyyn osallistui 1182 henkilöä, joista $77 \%$ oli miehiä ja $23 \%$ naisia. Tuloksia verrattiin edelliseen, vuoden 1992 seurantatutkimukseen ja koko suomalaiseen työssäkäyvään väestöön kohdistuvan "Työ ja terveys 2003" -tutkimuksen tuloksiin.

Kolmannes (34\%) kyselyyn vastanneista arvioi tuntevansa stressiä. Psyykkisen toimintakyvyn heikkenemistä esiintyi $36 \%$ :lla vastaajista. Neljänneksellä (26\%) vastaajista oli masennusoireita. Kaikkien oireiden esiintyvyys oli naisilla yleisempää kuin miehillä. Suurimmat erot olivat psyykkisen toimintakyvyn heikkenemisessä, jota koki $40 \%$ kyselyyn vastanneista naisista ja $33 \%$ miehistä, sekä masentuneisuudessa, jota koki $32 \%$ naisista ja $25 \%$ miehistä. Psyykkinen oireilu oli yleisempää eronneilla ja asumuserossa olevilla kuin muilla siviilisäätyryhmillä. Myös nuoret viljelijät oireilivat enemmän kuin ikääntyneet siten, että ikäryhmässä 35-45-vuotiaat stressin ja yleisen psyykkisen oireilevuuden esiintyminen oli yleisintä. Opisto- tai korkeakoulutuksen omaavilla stressiä esiintyi enemmän (41\%) kuin keskimäärin aineistossa.

Vertailu edellisen seurantatutkimuksen tuloksiin henkisen hyvinvoinnin osalta osoittaa, että psyykkistä oireilua esiintyi vuosien 1992 ja 2004 kyselyissä jotakuinkin yhtä paljon. Poikkeuksena tästä on masentuneisuus, joka oli yleisempää vuoden 2004 tuloksissa (26\%) kuin vuonna 1992 (20\%), ero oli tilastollisesti merkitsevä. Etenkin naisten keskuudessa masennusoireet olivat tilastollisesti merkitsevästi yleisempiä vuoden 2004 aineistossa (32\%) kuin vuonna 1992 toteutetussa seurantatutkimuksessa, jossa masennusoireita oli $22 \%$ :1la kyselyyn vastanneista naisista. Suomalaiseen työssäkäyvään väestöön tehdyn vertailun mukaan päätoimisesti maatiloilla työskentelevillä oli vähemmän psyykkisiä oireita kuin työssäkäyvillä keskimäärin. Maatilayrittäjillä oli myös vähemmän stressiä (34 \%) kuin työssäkäyvillä keskimäärin $(44 \%)$.

Henkisen hyvinvoinnin tulosten tarkastelussa on otettava huomioon viimeisten vuosien aikana toteutunut raju rakennemuutos: vuosien 1992 ja 2004 välillä maatilojen määrä on laskenut $41 \%$ ja maatiloilla työskentelevien henkilöiden määrä on laskenut $45 \%$. Erot maatalousyrittäjien henkisen hyvinvoinnin tasossa edellä mainittuina ajankohtina ovat kuitenkin suhteellisen vähäiset. Yksi selitysmahdollisuus on, että maatalouden harjoittajiksi ovat valikoituneet suhteellisen muutosvalmiit ja psyykkisiä voimavaroja omaavat henkilöt. Huomiota herättävää on kuitenkin masentuneisuuden lisääntyminen 12 vuoden tarkastelujakson aikana. Maatilayrittäjien parissa työskentelevien tulee ottaa huomioon alan nopean toimintaympäristön muuttumisen aikaansaamat paineet. Maatilataloudessa työskentelevät tarvitsevat tukea muutosten keskellä.

Asiasanat: maatila, maatalousyrittäjä, henkinen hyvinvointi, stressi, masentuneisuus, psyykkiset oireet 


\section{Johdanto}

Maatilatalouden rakennemuutos on ollut nopeaa viimeisten vuosikymmenten aikana. Millään muulla ammattialalla ei ole koettu yhtä nopeaa toimintaympäristön muutosta yhteiskunnassamme. Maatilojen määrän vähenemistä on vauhdittanut Suomen liittyminen Euroopan unionin jäseneksi vuonna 1995. Vuosien 1992-2004 välillä maatilojen määrä on laskenut 50262 tilalla eli $41 \%$ ja maatilayrittäjien määrä on laskenut 74000 henkilöllä eli $45 \%$. Samanaikaisesti jatkavien maatilojen koko on kasvanut 13,4 hehtaarilla: vuonna 1992 maatilojen keskimääräinen peltokoko oli 18,1 hehtaaria ja vuonna 2004 se oli kohonnut 31,5 hehtaariin. Maatilojen tuotantosuunnat ovat myös muuttuneet siten, että kotieläintilojen määrä on laskenut ja kasvinviljelytilojen määrä on vastaavasti noussut (Kettunen 1994, Niemi \& Ahlstedt 2005).

Tutkimuksissa on havaittu myös muita maaseutua koskevia muutoksia. Leskisen (2004) seurantatutkimus maitotalousyrittäjien henkisestä selviytymisestä toteutettiin vuosina 1997 ja 2001. Sen mukaan maaseudun kyläyhteisöt muuttuivat näinä vuosina siten, että yhteistyö naapureiden kanssa väheni ja myös viljelijäperheiden perhekäsitys muuttui perhekeskeisestä yksilön oikeuksia korostavaksi, mikä vähensi perheenjäsenten keskinäistä vuorovaikutusta. Ylipäätään yhteiskuntamme on ollut mukana modernisaatiokehityksessä, minkä yksi keskeisiä luonnehdintoja on epävarmuudessa eläminen (Beck 1995).

Maatilayrittäjien henkistä hyvinvointia on selvitetty aiemmissa tutkimushankkeissa melko vähän. Työterveyslaitoksen toteuttamien "Työ ja terveys Suomessa" -tutkimusten mukaan maatilayrittäjien kokema stressi on vähentynyt: vuonna 1997 maatilayrittäjistä $(n=166)$ $43 \%$ koki jonkin verran, melko tai erittäin usein stressiä, kun vastaava lukema vuonna 2006 $(\mathrm{n}=75)$ oli $30 \%$. Myös työelämässä mukana olevien kokema stressi on vähentynyt tasaisesti vuodesta 1997 (Kauppinen ym. 2007). Simolan ym. (1994) aiemman seurantatutkimuksen mukaan maatalousyrittäjien psyykkinen oireilevuus oli muihin ammattiryhmiin verrattuna keskimääräistä vähäisempää. On kuitenkin huomattava, että tuoreessa Saarnin ym. (2007) tutkimuksessa maatilayrittäjien $(n=129)$ työkyky, oma arvio elämänlaadusta ja terveyteen liittyvä elämänlaatu oli muihin yrittäjiin ja palkansaajiin verrattuna kaikkein alhaisin.

\section{Aineisto ja menetelmät}

Työterveyslaitos toteutti vuonna 2004 laajan maatalousyrittäjien työterveyden seurantatutkimuksen "Työterveys ja maatalous Suomessa 2004".Tietokoneavusteiseen puhelinkyselyn otos oli 2471 henkilöä. Henkisen hyvinvoinnin kysymykset kohdennettiin 1182 päätoimisesti maatilalla työskentelevälle henkilölle, joista 911 (77\%) oli miehiä ja 271 (23 \%) naisia. Vastaajat suhtautuivat haastattelupyyntöön varsin positiivisesti, jolloin osallistumisaktiivisuus kohosi korkeaksi, 86 prosenttiin (Rissanen toim. 2006). Tuloksia verrattiin edelliseen, vuonna 1992 toteutettuun maatalousyrittäjien seurantatutkimukseen (Susitaival 1994), johon vastasi 928 viljelijää. Lisäksi tuloksia verrattiin koko suomalaiseen työssäkäyvään väestöön kohdistuvan "Työ ja terveys 2003" -tutkimuksen (Piirainen ym. 2003) tuloksiin, johon vastasi 3331 henkilöä.

Henkistä hyvinvointia koskevissa kysymyksissä stressiä mitattiin Työstressikyselyn (Elo ym. 2003) kysymyksellä: "Stressillä tarkoitetaan tilannetta, jossa ihminen tuntee itsensä jännittyneeksi, levottomaksi, hermostuneeksi tai ahdistuneeksi tai hänen on vaikea nukkua asioiden vaivatessa jatkuvasti mieltä; tunnetko sinä nykyisin tällaista stressiä?” Psyykkistä oireilua selvitettiin Raitasalon (1992) kehittämästä oirepatteristosta puhelinhaastattelua varten laadituilla kysymyksillä, joiden avulla mitattiin psykosomattisia oireita, depressiivisyyttä, hermostuneisuutta, foobisuutta ja toimintakyvyn heikkenemistä.

Tuloksia tarkastellaan tässä vertailemalla prosenttilukuja. Eri aineistojen välisissä vertailuissa toteutettiin myös tilastolliset merkitsevyystestaukset siten, että vertailussa ikä ja sukupuoli vakioitiin. Merkitsevyystestaus toteutettiin z-testin avulla ja merkitsevyystaso oli $\mathrm{p}<$ 
0,05 . Menetelmät on kuvattu stressin osalta yksityiskohtaisesti tieteellisessä artikkelissa (Kallioniemi ym. 2008).

\section{Tulokset}

Kolmannes (34 \%) kyselyyn vastanneista maatilayrittäjistä kertoi tuntevansa jonkin verran, melko tai erittäin usein stressiä. Erot stressin esiintyvyydessä eri ikäryhmissä ja sukupuolten välillä olivat vähäisiä. Vastaajan koulutustaso vaikutti siten, että opisto- ja korkeakoulutuksen omaavilla stressin esiintyminen oli yleisempää (41\%) kuin aineistossa keskimäärin. Vastaajan siviilisääty vaikutti stressin määrään siten, että stressiä esiintyi eniten eronneilla ja asumuserossa olevilla henkilöillä (39\%). Tutkimuksen yksityiskohtaiset tulokset stressin osalta on esitetty Kallioniemen ym. (2008) artikkelissa.

Vertailu "Työ ja terveys 2003 Suomessa" tutkimuksen tuloksiin osoitti, että maatilayrittäjillä esiintyi vähemmän stressiä kuin keskimäärin suomalaisen työssäkäyvän väestön keskuudessa (44\%). Etenkin iäkkäämmissä ikäryhmissä stressiä esiintyi selkeästi vähemmän maatalousyrittäjillä kuin keskimäärin työssäkäyvillä.

Psyykkisen toimintakyvyn heikkenemistä esiintyi $36 \%$ :1la maatilayrittäjistä. Neljänneksellä $(26 \%)$ vastaajista oli masennusoireita. Kaikkien psyykkisten oireiden esiintyvyys oli naisilla yleisempää kuin miehillä. Suurimmat erot olivat psyykkisen toimintakyvyn heikkenemisessä, jota koki $40 \%$ kyselyyn vastanneista naisista ja $33 \%$ miehistä, sekä masentuneisuudessa, jota koki $32 \%$ naisista ja $25 \%$ miehistä. Psyykkinen oireilu oli yleisempää eronneilla ja asumuserossa olevien keskuudessa kuin muissa siviilisäätyryhmissä. Nuoret viljelijät oireilivat psyykkisesti enemmän kuin ikääntyneet siten, että ikäryhmässä 35-45-vuotiaat stressin ja yleisen psyykkisen oireilevuuden esiintyminen oli yleisintä. Henkisesti parhaiten voivat 55-64-vuotiaat maatalousyrittäjät.

Vertailu edellisen seurantatutkimuksen tuloksiin henkisen hyvinvoinnin osalta osoittaa, että psyykkistä oireilua esiintyi 1992 ja vuoden 2004 kyselyissä jotakuinkin yhtä paljon. Poikkeuksena tästä on masentuneisuus, joka oli yleisempää vuoden 2004 tuloksissa $(26 \%)$ kuin vuonna 1992 (20\%) ja ero oli tilastollisesti merkitsevä. Etenkin naisten keskuudessa masennusoireet olivat tilastollisesti merkitsevästi yleisempiä vuoden 2004 aineistossa (32\%) kuin vuonna 1992 toteutetussa seurantatutkimuksessa, jossa masennusoireita oli $22 \%$ :1la kyselyyn vastanneista naisista. Suomalaiseen työssäkäyvään väestöön tehdyn vertailun mukaan päätoimisesti maatiloilla työskentelevillä oli pääsääntöisesti vähemmän psyykkisiä oireita kuin työssäkäyvillä keskimäärin. Masentuneisuutta esiintyi kuitenkin yhtä paljon maatilayrittäjillä ja työssäkäyvillä keskimäärin. Masentuneisuus oli selkeästi yleisempää eronneiden ja asumuserossa olevien maatilayrittäjien keskuudessa (45\%) kuin aineistossa keskimäärin (26 $\%)$.

\section{Tulosten tarkastelu}

Tulosten tarkastelussa yksi selitysmahdollisuus maatilayrittäjien henkisen hyvinvoinnin verrattaen hyvälle tasolle on se, että maatalouden harjoittajiksi ovat valikoituneet suhteellisen muutosvalmiit ja psyykkisiä voimavaroja omaavat henkilöt. Tätä näkökantaa tukee tutkimus norjalaisten maatilayrittäjien ( $n=1408)$ stressistä ja psyykkisestä hyvinvoinnista, jonka johtopäätösten mukaan viljelijät ovat kyenneet muuntumaan olosuhteiden mukaan eivätkä ole stressaantuneita. Ammatin myönteisinä puolina mainitaan puhdas ilma, kontaktit eläimiin, vapaus ja riippumattomuus (Melberg 2003).

Kyselytutkimus kykenee mittaamaan henkisen hyvinvoinin tasoa ja oireita tiettynä ajankohtana. Tämän vuoden 2004 tilanteeseen perustuvan tutkimuksen tuloksiin vaikuttavia tekijöitä saattavat olla vuodenaika, poliittinen tilanne ja yhteiskunnassa käytävä julkinen keskustelu. 
Gregoire (2002) pohtii kirjallisuusartikkelissaan, että henkisen sairaudet aiheuttavat maatalousyhteisöissä leimautumista ja tietämys niiden osalta saattaa olla puutteellista. Nämä tekijät saattavat vaikuttaa siihen, miten aktiivisesti apua haetaan terveydenhuollon piiristä henkisen hyvinvoinnin ongelmiin. Näillä tekijöillä saattaa olla merkitystä myös Suomessa, jossa terveyspalveluja tarjoavat kunnat ovat pieniä, jolloin leimautumisen vaara saattaa olla todellinen. On syytä pitää mielessä Saarnin ym. (2007) tutkimuksen tulokset, joiden mukaan suomalaiset maatilayrittäjät kokivat elämänlaatunsa heikoimmaksi muihin yrittäjiin ja palkansaajiin verrattuna. Maaseutu on käynyt läpi maassamme viime vuosikymmenten aikana nopean toimintaympäristön muutoksen, mitä yksikään muu ammattiala ei ole yhteiskunnassamme kohdannut.

\section{Johtopäätökset}

Erot maatalousyrittäjien henkisen hyvinvoinnin tasossa vuosina 1992 ja 2004 olivat suhteellisen vähäisiä. Stressiä ja psyykkistä oireilua esiintyi maatilayrittäjillä pääsääntöisesti vähemmän kuin keskimäärin työssäkäyvillä henkilöillä. Huomiota herättävää on kuitenkin maatilayrittäjien masentuneisuuden lisääntyminen 12 vuoden tarkastelujakson aikana. Eroaminen tai asumusero on riski henkiselle hyvinvoinnille. Maatalousyrittäjän ikä vaikuttaa siten, että nuoret viljelijät oireilivat psyykkisesti enemmän ja ikääntyneet maatilayrittäjät voivat henkisesti parhaiten. Maatilayrittäjien parissa työskentelevien tulee ottaa huomioon alan nopean toimintaympäristön muuttumisen aikaansaamat paineet. Maatilataloudessa työskentelevät tarvitsevat tukea muutosten keskellä.

\section{Kirjallisuus:}

Beck U. 1995. Politiikan uudelleen keksiminen: Kohti refleksiivisen modernisaation teoriaa. Teoksessa: Beck U, Giddens A. \& Lash S. Nykyajan jäljillä. Refleksiivinen modernisaatio. Tampere: Vastapaino. $301 \mathrm{s.}$

Elo A.-L., Leppänen A., Jahkola A. 2003. Validity of a single-item measure of stress symptoms. Scand J Work, Environ and Health 29:444-451.

Gregoire A. 2002. The mental health of farmers. Occupational Medicine vol. 52, no 8, pp. 471-476.

Kallioniemi, M., Simola A., Kymäläinen H.-R., Vesala H. \& Louhelainen K. 2008. Stress among Finnish full-time farm women and men. Submitted manuscript.

Kauppinen T, Hanhela R, Heikkilä P, Kasvio A., Lehtinen S., Lindström K., Toikkanen J., Tossavainen A. 2007. Työ ja terveys Suomessa 2006. Helsinki: Työterveyslaitos. 462 p.

Kettunen L. 1994. Suomen maatalous vuonna 1993. Maatalouden taloudellisen tutkimuslaitoksen julkaisuja nro $73.51 \mathrm{~s}$.

Leskinen J. 2004. Saloseudulta EU-isänäksi - lypsykarjayrittäjät muutosmurroksessa. Seurantatutkimus 1997 2001. Helsinki: Työterveyslaitos. Työ ja ihminen, Tutkimusraportti 24:146 s. 2 liitettä.

Melberg K. 2003. Farming, Stress and Psychological Well-being: The Case of Norwegian Farm Spouses. Sociologia Ruralis, vol. 43 , pp. 56-76

Niemi J. \& Ahlstedt (eds.) 2005. Suomen maatalous ja maaseutuelinkeinot 2005. MTT taloustutkimus, julkaisuja 105. Agrifood Research Finland, Economic Research, Publications 107. 94 p. In Finnish.

Piirainen H, Hirvonen M, Elo A-L, Huuhtanen P, Kandolin I, Kauppinen K, Ketola R, Lindström K, Salminen S, Reijula K, Riala R, Toivanen M, Viluksela M, Virtanen S. 2003. Työ ja terveys haastattelututkimus. Taulukkoraportti. Helsinki: Työterveyslaitos. 377 p.

Raitasalo R. 1992. Psyykkinen oireilu, hoidon tarve ja hoidon käyttö. In: Kalimo E., Klaukka T., Lehtonen R., Nyman K. Suomalaisten terveysturva ja sen kehitystarpeet. Kansaneläkelaitoksen julkaisuja M: 81, p. 107-128.

Rissanen P. (toim.) 2006. Työterveys ja maatalous Suomessa 2004. Maatalousympäristön terveydelliset riskit ja niihin vaikuttaminen. Kuopio: Työterveyslaitos. $101 \mathrm{~s}$.

Saarni S. I., Saarni E. S., Saarni H. 2007. Quality of life, work ability, and self employment: a population survey of entrepreneurs, farmers, and salary earners. Occup Environ Med 2007 (available online DOI 10.1136/oem.2007.033423)

Simola A., Notkola V. \& Raitasalo R. 1994. Mielenterveyden ongelmat. Teoksessa: Susitaival P. (toim.) Työterveys ja maatalous. Tutkimus maatalousyrittäjien työterveyshuollosta, terveydentilasta ja työssä viihtymisestä. Helsinki: Kansaneläkelaitos. Kansaneläkelaitoksen julkaisuja ML 133. 232 s.

Susitaival P. (toim.) 1994. Työterveys ja maatalous Suomessa 1992. Tutkimus maatalousyrittäjien työterveyshuollosta, terveydentilasta ja työssä viihtymisestä. Helsinki: Kansaneläkelaitos. Kansaneläkelaitoksen julkaisuja ML 133. $232 \mathrm{~s}$. 